\title{
Consumers Acceptance and Intention to Forward EWOM Messages: The Influences of Volume, Valence, Content Quality, Source Credibility and Homophily
}

\author{
Hai Ninh Nguyen ${ }^{1 *}$ \\ Huong Tra Thi $\mathrm{Vo}^{2}$ \\ School of International Business and Economics ${ }^{1 \& 2}$ \\ Foreign Trade University, Vietnam ${ }^{1 \& 2}$
}

\begin{abstract}
The emergence of online communities and social media has gradually transformed the way society works. It has motivated people to generate and spread electronic word of mouth (EWOM) intentionally and unintentionally. Today, people and consumers move from passive information receivers to more active experiencers. This research aims at understanding the nature of customer acceptance, intention to forward EWOM messages, and the impacts of volume, valence, source credibility, and homophily on these mentioned behaviors. An online structured questionnaire and PLS-SEM statistical technique were used to test. The results from the data analysis of 367 respondents showed significance and positivity in all examined relationships. The acceptance of the EWOM message has a substantial impact on the intention to forward it. The EWOM acceptance was influenced by all proposed independent factors, whereas the forwarding intention was determined by three factors of source credibility, homophily, and acceptance of EWOM.
\end{abstract}

Keywords: Electronic Word of Mouth, Content Quality, EWOM Volume, EWOM Valence, Source Credibility, Homophily, Acceptance of EWOM, Forwarding Intention of EWOM.

*Corresponding author: Hai Ninh Nguyen; Email: nguyen.haininh@ftu.edu.vn DOI: https://doi.org/10.37227/JIBM-2021-09-1188

\section{Introduction}

The digital era is witnessing an explosion of consumer-generated content via the Internet, drawing many researchers and marketing practitioners' attention (Rahman \& Haque, 2021). With the advent and growth of the Internet and social media, consumers have radically been transformed from the role of a passive recipient of the information provided by brands to more active experiencers and content creators (Srivastava \& Sivaramakrishnan, 2020). Consumers nowadays observe, participate, interact, and co-create with brands and other consumers (Labrecque et al., 2013; Ahmed \& Latif, 2018), expressed as electronic word-of-mouth (EWOM).

EWOM is defined as any positive or negative statement made by potential, actual, or former customers about a product or company, which is made available to a multitude of people and institutions via the Internet (Hennig-Thurau et al., 2004). Consumer-to-consumer communication about products and brands is perceived more trustworthy than messages with promotional efforts 
from companies (Mangold \& Faulds, 2009). It can provide them information about product ratings, comments, or posted extensive reviews on various sites (Al-Htibat \& Garanti, 2019).

Nielsen (2012) reported that the opinions, tastes and preferences of an exponentially larger, global pool of friends, peers and influencers have driven consumer decisions and behaviors, and the effect of online recommendations is larger than the objective product benefits (Hu et al., 2011). When receivers forward EWOM to other people in their social network, it creates a viral or ripple effect that facilitates exponential dispersion (Dobele et al., 2007). However, easy access and quick dissemination of information on the Internet raises the concern regarding lousy information about brands or products, potentially resulting in sales decrease and even bad reputation for brands. Therefore, marketers need to understand customers' adoption of EWOM information from their acceptance to subsequent forwarding of the EWOM.

Earlier research mainly investigated antecedents of EWOM, the impact of EWOM on consumer decision-making process (De Bruyn \& Lilien, 2008), and attitude towards brand/website (Lee et al., 2009). Based on some studies on AEWOM and FEWOM, typically the research by Mahapatra \& Mishra (2017), this paper examines the impact of content quality, EWOM volume, EWOM valence, source credibility, and homophily on acceptance of EWOM as well as the influence of source credibility and homophily on the forwarding of EWOM.

\section{Electronic Word-of-Mouth (EWOM)}

\section{Literature Review}

Word-of-mouth (WOM) was identified in 1967 by Johan Arndt as an essential marketing phenomenon (Arndt, 1967; Baka, 2016; Sweeney et al., 2014) and has been frequently studied for many years. According to Arndt (1967), traditional WOM is defined as oral, person-to-person communication between a receiver and a communicator whom the receiver perceives as noncommercial, concerning a brand, product, or a service.. The invention and growth of the Internet and social media changed traditional WOM and transformed it into electronic word-of-mouth or EWOM for short (Mishra \& S M, 2016). The term EWOM refers to providing and receiving information and informal advice on products and services within media outlets (Abrantes et al., 2013), whereby communicator and recipient are separated in space and time (Steffes \& Burgee, 2009). HennigThurau et al. (2004) stated that EWOM is "any positive or negative statement made by potential, actual, or former customers about a product or company, which is made available to a multitude of people and institutions via the Internet". From another perspective, EWOM is considered a form of peer-to-peer communication via electronic means (Vilpponen et al., 2006) and plays a significant role in marketing campaigns and managerial strategies (Hennig-Thurau et al., 2004).

Blau (1964) mentioned the social exchange theory, which proposes that people demonstrate different behaviors after evaluating the potential benefit of other products and then will choose one of them. Central to this theory is the principle of reciprocity in the form of rewards for information, which makes interpersonal interaction a process whereby parties conduct activities and exchange valuable resources. Therefore, identifying determinants of individuals' information sharing and forwarding in virtual communities is of great significance as it can stimulate information sharing behavior (Bordia et al., 2006). Moreover, Nguyen (2021) argues that eWOM is one of the main outcomes of consumer emotion when they have experience with brand and products.

\section{Acceptance and forwarding of EWOM}

Accepting EWOM (AEWOM) refers that a recipient believes EWOM information is accurate and likely to be valid (Mahapatra \& Mishra, 2017). Forwarding of EWOM (FEWOM) refers to the recipient's intention to resend the information received (Gershoff et al., 2003). The elaboration likelihood model (ELM), one of the most frequently used theoretical frameworks for EWOM (Chan and Ngai, 2011; Park and Lee, 2008; Gupta and Harris, 2010), is incorporated in this study. According to ELM, individuals will process EWOM using either a 'central' or 'peripheral' route (Fan et al., 2013) before accepting and forwarding information. In the ELM, those who process information through the central route emphasize argument-based processing, scrutinizing the merits 
and relevance of the arguments before forming an attitude about a product or advertisement. Individuals who process information through the peripheral route, on the other hand, make less effort cognitively and rely on alternative means such as a number of arguments and the physical attractiveness of endorsers when forming attitudes (Petty \& Cacioppo, 1986).

The central route in this current study is manifested in content quality. At the same time, EWOM volume, EWOM valence, source credibility, and homophily between receivers and senders are examined in the peripheral route. Based on the ELM, Sussman and Siegal (2003) indicated that consumers decide to forward EWOM only when they accept the information's validity, which depends on its source and credibility. Reviews (a form of EWOM) perceived as credible will be considered valuable, sound, and accepted and shared, causing widespread dissemination, thereby lengthening the word-of-mouth chain (Huang et al., 2011). In another study by Cheung et al. (2008), the authors employed an information adoption model and found a strong link between perceived information usefulness and its subsequent spread among online communities.

\section{- H1: Acceptance of EWOM has a positive impact on the forwarding of EWOM.}

\section{EWOM Volume}

According to Chen, Wang \& Xie (2011), EWOM volume inherently delivers information about the number of people who have experienced or used the product and its popularity in the market, hence increasing consumers' awareness of and reducing their uncertainty about the product leading to an increase in sales. Van den Bulte and Lilien (2001) explained this by the Bandwagon effect in which the mere availability of other consumers' opinions influences other consumers, regardless of the positivity or negativity of these opinions (Godes \& Mayzlin, 2009; Xiong \& Bharadwaj, 2014).

In addition, the tendency to rely on the amount of peer-generated information in consumers' decision-making process can be explained by herding behavior and social impact theory. People tend to follow the previous behavior of others to reduce risk in the environment (Banerjee, 1992; Latané, 1981). Furthermore, the more consumers discuss a product; the greater is the chance that other consumers will become aware of it because message repetition attracts people's attention to the topic of the message (Cacioppo \& Petty, 1989; Tellis, 1988). A study conducted by Park et al. (2007) also pointed that the volume of EWOM has a positive impact on customers' EWOM information adoption.

- H2: EWOM volume is positively associated with acceptance of EWOM.

\section{Content Quality}

Veer (2011b) stated that people on the Internet might disguise their identities. Therefore, it is difficult for receivers to determine the credibility and identity of eWOM generators. Thus, the quality of content is an essential variable for customers to evaluate EWOM and make wise decisions. According to Bhattacherjee and Sanford (2006), information quality refers to the persuasive strength of the message and includes various components such as relevance, timeliness, accuracy, and comprehensiveness (Luo et al., 2014).

DeLone and McLean (2003) pointed out that accuracy, relevance, understandability, completeness, currency, dynamism, personalization, and variety are the information quality measures used in recent e-commerce studies. Feldman \& Lynch (1988) and Herr et al. (1991) suggested that if the input information is clear and relevant, helping customers know more about products, that information is perceived as useful in their decision-making process. Jiménez \& Mendoza (2013) also discovered that the more detailed comments are, the more diagnostic they are (i.e. sound). Consumers are concerned about the correctness and usefulness of eWOM, and the quality of good content increases their readiness to trust eWOM (Awad \& Rogowsky, 2008). Information quality as a central cue plays a vital role in informational influence (Sussman \& Siegal, 2003) and is found to impact information adoption (Watts \& Zhang, 2008). In a study by Gershoff et al. (2003), quality was demonstrated as a judgment criterion for web users' online information acceptance decisions.

\section{- H3: Content quality is positively associated with acceptance of EWOM.}




\section{EWOM Valence}

The third component affecting EWOM influence is EWOM valence. "Valence" pinpoints the nature of the information, which could reveal a neutral, positive, or negative tone (Amblee \& Bui, 2011). For some products, negative EWOM is more appreciated and considered more informative than positive ones (Schindler \& Bickart, 2012). Other researchers found that unfavorable information is generally more influential than favorable information (Fiske, 1980; Chiou \& Cheng, 2003).

Negative product-related information helps customers identify products of low quality because negativity is associated with impaired quality (Skowronski \& Carlston, 1987; Herr et al., 1991). However, on EWOM platforms, products with overwhelmingly positive reviews are more recommended to friends than products with primarily negative reviews (Kudeshia \& Kumar, 2017). Lin \& Xu (2017) discussed that while negative objective reviews are "most useful for purchasedecision making, both an objective and subjective positive review significantly increase productrelated attitude and purchase intention". Positive eWOM not only strengthens the connection between the consumer's trust on an emotional level and the purchase intention but improves consumers' perceived integrity (Lin \& Xu, 2017). According to Amblee and Bui (2011), this results in favorable brand attitude, whereas if consumers gain negative experiences and switch brands, their friends will be discouraged from buying the product.

- H4: EWOM valence is positively associated with acceptance of EWOM.

\section{Source Credibility}

Source credibility has been considered a crucial determinant of EWOM influence (Menkveld, 2013; Sweeney et al., 2008), especially in an online environment where participants lack personal relationships. Petty et al. (1981) suggested that source credibility implies the extent to which a source is believed to be knowledgeable and trustworthy. However, due to the ability to disguise the identities of EWOM generators, proper source credibility evaluation is hard to be achieved as in traditional WOM (Duan et al., 2008). Thus, one feasible method to evaluate this aspect in EWOM environment is to be based on the most outstanding information about communicators, such as reputation and their trustworthiness expressed as the number of votes by other participants or the number of posts created by them in those online communities (Cheung et al., 2009).

Source credibility is also considered as a two-dimensional construct, including source expertise and source trustworthiness (Cheung et al., 2008; Cheung et al., 2012; Brown et al., 2007; Sussman et al., 2003). Specifically, expertise refers to the perceived ability of information providers (Brown et al., 2007), and trustworthiness is defined as "message source's perceived motivation to provide accurate and truthful information" (Cheung \& Thadani, 2012). Online reviews are based on the former experience of using the products or services. There are no financial motives for the recommendations from the reviewers' perspective, so the reliability of the message source is not questioned (Hass, 1981). Furthermore, according to Pongjit \& Beise-Zee (2015), senders' expertise is an essential factor for a recommendation to be passed on and followed.

- H5: Source credibility is positively associated with acceptance of EWOM.

- H6: Source credibility is positively associated with the forwarding of EWOM.

\section{Homophily}

Homophily is the degree to which individuals who interact with one another are similar in certain attributes (Rogers \& Bhowmik, 1970; Chu \& Kim, 2011), such as age, gender, educational background, or lifestyle. It is also defined as "the similarities between two people's values, likes, dislikes, and experience" (De Bruyn \& Lilien, 2008).

Previous studies showed that individuals in a social network demonstrating a natural similarity more frequently exchange communication (Rogers, 1995; Gilly et al., 1998). Therefore, homophily is also a factor resulting in an individual joining an online community (Thelwall, 2009). According to Wang et al. (2008), a positive relationship exists between similarity degree and perceived trustworthiness level in websites and online communities. Similarly, Fan and Miao (2012) suggested that homophily increases EWOM reliability and influence. In Cho et al. (2014) study, messages from known group members who enjoy high trust and harmonious relationships are more 
likely to be noticed, opened, and forwarded. The message is perceived to be more informative, entertaining, and less risky (Hansen, 1999; Mazzarol et al., 2007).

- H7: Homophily is positively associated with acceptance of EWOM.

- H8: Homophily is positively associated with forwarding of EWOM.

\section{Research Methodology}

Based on previous studies by different authors, typically Mahapatra \& Mishra (2017) and Abd-Elaziz et al. (2015), this research proposes an integrated model with Acceptance of EWOM and Forwarding EWOM examined. (Figure 1)

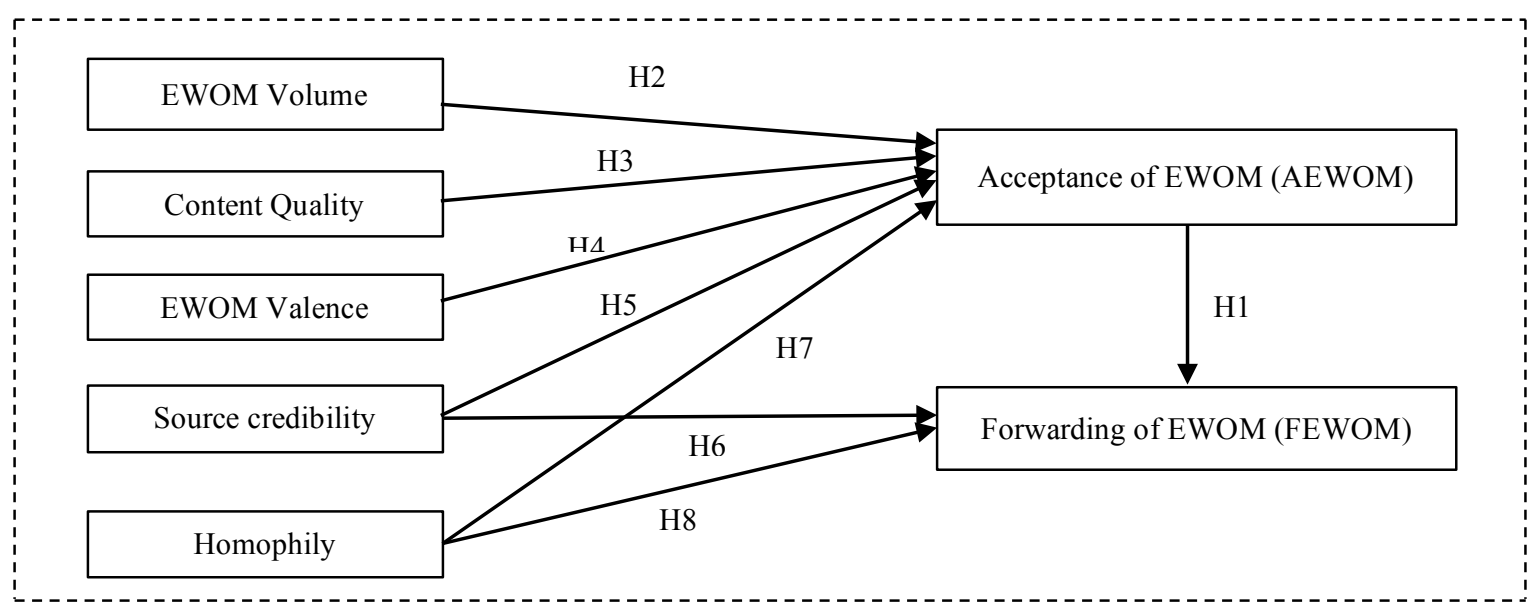

Figure 1: Proposed Research Model

The Partial least squares path modeling (PLS-SEM), Microsoft Excel, and Smart PLS 3.3 were utilized to execute descriptive analysis and statistical analysis. Andersen and Kheam (1988) stated that PLS - SEM is a two-step process involving the measurement and structural model assessment. Firstly, the measurement model is assessed by 4 criteria, including Cronbach's alpha (CA), Composite reliability (CR), Convergent validity (CV), and Discriminant validity (DV) (Hair et al., 2016). Secondly, the criteria for assessing the structural model are collinearity, the significance of the path coefficients, the level of the R2 values, the $\mathrm{f} 2$ effect size, and the predictive relevance Q2.

\section{Measurement Constructs Development}

In this study, the measurements of AEWOM and FEWOM applied a 4-item instrument from Wu \& Shaffer (1987) and Gershoff et al. (2003), and a 3-item instrument from Sun et al. (2006), respectively. EWOM volume measurement was based on a 5-item instrument adapted from separate studies by Teng et al. (2014), Lin et al. (2013), and El-desouky (2011), while EWOM valence was measured by a 6-item instrument developed by Yayli \& Bayram (2012). To measure content quality construct, a 5-item instrument was synthesized from 4 different studies by Lin et al. (2012), Sundar (1998), Teng et al. (2014), and Filieri \& McLeay (2014). Next, a combination of Ohanian (1990) and Lin et al. (2013) studies were also applied to develop a 4-item instrument to measure source credibility. Finally, 3 items from Andersen \& Todd de Mancillas (1978) were included as a measurement for homophily construct.

Measurements for all items were carried out by a five-point Likert scale (Bryman and Bell, 2011) ranging from 1 (strongly disagree) to 5 (strongly agree). The pretest questionnaire was distributed to 50 respondents to examine the scale's psychometric properties and to evaluate the validity and reliability of the scale. 


\section{Data Collection and Sample Profile}

This study focuses on electronic word-of-mouth. A structured online questionnaire was developed and sent out to anyone using the Internet via various channels, including Facebook, Instagram, Zalo, and emails. This survey lasted from April 2021 to July 2021 and received 367 clean and complete questionnaires after quality checks and accounting for invalid or incomplete responses.

The demographic profile of the sample is demonstrated in the below table. The figures show that men and women account for $41.7 \%$ and $58.3 \%$ of the sample profile, respectively. Most of the respondents are young people ranging from 18 to 35 years old, with $44.1 \%$ in $18-23$ age group and $36.5 \%$ belonging to $24-35$ age group. The educational level is also shown in the table, demonstrating the highest percentage (50.4\%) as undergraduates, followed by $26.4 \%$ of high school individuals and $23.2 \%$ of postgraduates. In terms of occupation, office workers constitute $40.6 \%$ of respondents, and $37.9 \%$ are undergraduates. Respondents who earn 2-5 million VND and 5-10 million VND make up $38.1 \%$ and $31.3 \%$ of the sample, while the higher income group constitutes $27 \%$.

Table 1. Demographic descriptive profile of respondents $(n=367)$

\begin{tabular}{l|l|l|l}
\hline Demographic variables & Category & Frequency & Percentage (\%) \\
\hline Gender & Male & 153 & 41.7 \\
& Female & 214 & 58.3 \\
\hline Age & $<18$ & 7 & 1.9 \\
& $18-23$ & 162 & 44.1 \\
& $24-35$ & 134 & 36.5 \\
& $36-45$ & 45 & 12.3 \\
& $>45$ & 19 & 5.2 \\
\hline Educational level & High school & 97 & 26.4 \\
& Undergraduate & 185 & 50.4 \\
& Postgraduate & 85 & 23.2 \\
\hline Occupation & Manager/Executive & 22 & 6.0 \\
& Office worker & 149 & 40.6 \\
& Student & 17 & 4.6 \\
& Undergraduate & 139 & 37.9 \\
& Freelancer & 13 & 4.9 \\
& Unemployed & 14 & 3.8 \\
& Others & 8 & 2.2 \\
\hline Monthly income & $<2$ & 13 & 3.5 \\
(million VND) & $2-5$ & 140 & 38.1 \\
& $5-10$ & 115 & 31.3 \\
& $>10$ & 99 & 27.0 \\
\hline
\end{tabular}

\section{Results and Analysis}

\section{Measurement Model Assessment}

In PLS-SEM analysis, the first step is to measure the measurement model. According to Hair et al. (2010), the measurement model demonstrates the relationships between constructs and corresponding items. The two main criteria for this assessment are reliability and validity (Ramayah et al., 2011). Reliability tests examine the stability and consistency of items in the same construct. In contrast, validity tests are executed to determine whether an item accurately reflects the particular concept it is designed to measure (Sekaran \& Bougie, 2010).

In terms of internal consistency reliability, Cronbach's Alpha and Composite reliability are most commonly used to measure the reliability based on the intercorrelations of the observed indicator items (Hair et al., 2016). The internal consistency reliability is said to be achieved when the Cronbach's Alpha value is 0.7 or higher (Nunnally \& Beinstein, 1994). Composite reliability values 
of 0.60 to 0.70 are acceptable in exploratory research, while in more advanced stages of research, values between 0.70 and 0.90 can be regarded as satisfactory.

The next step is the assessment of validity, which is examined with a construct's convergent validity and discriminant validity. Convergent validity is to measure the level of correlation of multiple indicators of the same construct (Hamid et al., 2017). It is said that convergent validity is achieved when each item has outer loadings above 0.70 and when each construct's average variance extracted (AVE) is 0.50 or higher (Hair et al., 2014). Discriminant validity represents the extent to which a construct is empirically distinct from other constructs (Hair et al., 2014). Accordingly, each construct's AVE square root should have a greater value than the correlations with other latent constructs.

Table 2. Reliability and Convergent Validity

\begin{tabular}{|l|l|l|l|l|}
\hline & $\begin{array}{l}\text { Cronbach's } \\
\text { Alpha }\end{array}$ & Outer Loadings & $\begin{array}{l}\text { Average } \\
\text { Composite } \\
\text { Reliability }\end{array}$ & $\begin{array}{l}\text { Variance } \\
\text { Extracted } \\
\text { (AVE) }\end{array}$ \\
\hline AEWOM & 0.863 & $0.771-0.875$ & 0.907 & 0.709 \\
\hline CQ & 0.849 & $0.730-0.813$ & 0.893 & 0.625 \\
\hline EVA & 0.882 & $0.724-0.835$ & 0.910 & 0.629 \\
\hline EVO & 0.856 & $0.769-0.820$ & 0.897 & 0.634 \\
\hline FEWOM & 0.845 & $0.852-0.888$ & 0.907 & 0.764 \\
\hline HOM & 0.848 & $0.868-0.881$ & 0.908 & 0.767 \\
\hline SC & 0.849 & $0.825-0.833$ & 0.898 & 0.688 \\
\hline
\end{tabular}

By running the PLS-SEM algorithm, the analysis result shows that all Cronbach's Alpha values range from 0.845 to 0.882 and Composite reliability values are between 0.893 and 0.910 , satisfying threshold values and achieving internal consistency reliability. Each construct's AVE and outer loadings satisfy threshold values of 0.50 and 0.70 , respectively, achieving convergent validity. As a result, shown in table 3, all of the square roots of each construct' AVE values are greater than the correlations in their respective columns and rows, indicating that all the constructs used in this research have discriminant validity.

Table 3. Discriminant Validity

\begin{tabular}{|l|l|l|l|l|l|l|l|}
\hline & AEWOM & \multicolumn{1}{|c|}{ CQ } & EVA & EVO & FEWOM & HOM & SC \\
\hline AEWOM & $\mathbf{0 . 8 4 2}$ & & & & & & \\
\hline CQ & 0.548 & $\mathbf{0 . 7 9 1}$ & & & & & \\
\hline EVA & 0.452 & 0.405 & $\mathbf{0 . 7 9 3}$ & & & & \\
\hline EVO & 0.470 & 0.474 & 0.285 & $\mathbf{0 . 7 9 6}$ & & & \\
\hline FEWOM & 0.585 & 0.456 & 0.370 & 0.383 & $\mathbf{0 . 8 7 4}$ & & \\
\hline HOM & 0.426 & 0.238 & 0.212 & 0.260 & 0.378 & $\mathbf{0 . 8 7 6}$ & \\
\hline SC & 0.535 & 0.381 & 0.218 & 0.331 & 0.500 & 0.349 & $\mathbf{0 . 8 2 9}$ \\
\hline
\end{tabular}

\section{Structural Measurement Model}

Before assessing the structural measurement model, the quality of the model was checked by testing the model fit expressed as Standardized Root Mean Square Residual (SRMR). According to Hu \& Bentler (1998) and Hair et al. (2014), the standard for acceptable fit is that SRMR should be less than 0.08 . The result of Table 5 shows the SRMR value of 0.046 - less than the threshold (0.08) indicating the good fit of the model for theory testing.

After satisfying the above prerequisites, the next step is to evaluate the structural model, which describes the relationships between the latent constructs themselves (Hair et al., 2017). In a study published in 2016, Hair et al. proposed five steps to do this measurement including: (1) 
Assessing the structural model for collinearity issue, (2) Assess the significance of the path coefficient, (3) Assess the level of R2 values, (4) Assess the effect size (f2), (5) Assess the predictive relevance $(\mathrm{Q} 2)$.

According to Shiu et al. (2009), multicollinearity presents the situation where several independent variables correlate. As a result, it is impossible to estimate the separate effect of the independent variable on the dependent variable. In this study, the variance inflation factor (VIF) is used to assess multicollinearity severity. The VIF value of greater than 5 means high collinearity, which is problematic (Saunders et al., 2012; Shiu et al., 2009), and VIF below 5 signifies that multicollinearity is not a problem (Shiu et al., 2009). The analysis results of this study show that the lowest VIF value is 1.523 and the highest value is 2.350 , all are lower than 5 so there is no critical collinearity issue among the predictor constructs in the structural model.

After running the PLS model, estimates are provided for the path coefficients ( $\beta$ values), representing the hypothesized relationships linking the constructs. They have standardized values approximately between -1 and +1 (Hair et al., 2016), with coefficients closer to +1 representing strong positive relationships and vice versa. The closer the estimated coefficients are to 0 , the weaker the relationships are. Testing the significance for the regression weights is achieved by running 5000 bootstrapped samples from the original 367 cases. As demonstrated in the table below, all the relationships see positive impacts and are significant because $\mathrm{p}$ values are all $<0.05$. More specifically, the influence of AEWOM on FEWOM is the strongest in this model with path coefficient of 0.404 , whereas the relationship between HOM and FEWOM sees the weakest effect $(0.121)$.

The third step is calculating R2 value, which measures the model's predictive power (Hair et al., 2016). R2 value indicates the amount of the variance in the dependent variable that is explained by the independent variables Cohen (1998) stated that $\mathrm{R} 2$ values of $0.26,0.13$, and 0.02 respectively represent the substantial, moderate, and weak levels of predictive accuracy. As shown in Table 5, the $\mathrm{R} 2$ value of $\mathrm{AEWOM}=0.529$ and FEWOM $=0.402$, representing a substantial level. These values mean that independent variables explain $52.9 \%$ of AEWOM variance and $40.2 \%$ of FEWOM variance.

Table 4. R2, Q2 and SRMR

\begin{tabular}{|c|c|c|c|}
\hline & $\mathbf{R}^{\mathbf{2}}$ & $\mathbf{Q}^{\mathbf{2}}$ & \multirow{2}{*}{ SRMR } \\
\cline { 1 - 3 } AEWOM & 0.529 & 0.367 & \multirow{2}{*}{0.046} \\
\cline { 1 - 3 } FEWOM & 0.402 & 0.299 & \\
\cline { 1 - 3 }
\end{tabular}

The effect size (f2) test evaluates whether exogenous constructs have a substantive impact on endogenous constructs. The path coefficient cannot provide any information about the effect size of the exogenous latent variables on the endogenous construct. Cohen (1988) gives the guidelines to assess the $\mathrm{f} 2$ whereby $0.02,0.15$, and 0.35 indicate small, medium, and large effects. From the analysis result, only the relationship between AEWOM and FEWOM sees a medium effect size with $\mathrm{f} 2=0.177$, while the other relationships' effect is small $(0.020$ to 0.130$)$.

Table 5. Hypothesis Testing

\begin{tabular}{|c|l|c|c|c|c|c|}
\hline Hypothesis & \multicolumn{1}{|c|}{ Path } & $\boldsymbol{\beta}$ & $\boldsymbol{t}$ & $\boldsymbol{f}^{\mathbf{2}}$ & $\boldsymbol{P}$ & Decision \\
\hline H1 & AEWOM - FEWOM & 0.404 & 7.685 & 0.177 & 0.000 & Supported \\
\hline H2 & EVO - A AEWOM & 0.156 & 3.307 & 0.038 & 0.001 & Supported \\
\hline H3 & CQ -> AEWOM & 0.237 & 5.037 & 0.078 & 0.000 & Supported \\
\hline H4 & EVA -> AEWOM & 0.211 & 4.972 & 0.077 & 0.000 & Supported \\
\hline H5 & SC -> AEWOM & 0.282 & 6.824 & 0.130 & 0.000 & Supported \\
\hline H6 & SC -> FEWOM & 0.241 & 5.409 & 0.068 & 0.000 & Supported \\
\hline H7 & HOM -> AEWOM & 0.186 & 4.392 & 0.062 & 0.000 & Supported \\
\hline H8 & HOM -> FEWOM & 0.121 & 2.864 & 0.020 & 0.004 & Supported \\
\hline
\end{tabular}

Note: $\beta=$ Original Sample, $t=$ T statistics, $f^{2}=f$ square 
Upon the determination of the effect size (f2), the final step is to assess the predictive relevance (Q2) of the model (Hair et al., 2016). Hair et al. (2016) suggested that, in the structural model, Q2 values larger than zero for a specific reflective endogenous latent variable indicate the path model's predictive relevance for a particular dependent construct. The calculation shows values of 0.367 and 0.299; hence AEWOM and FEWOM have acceptable predictive relevance.

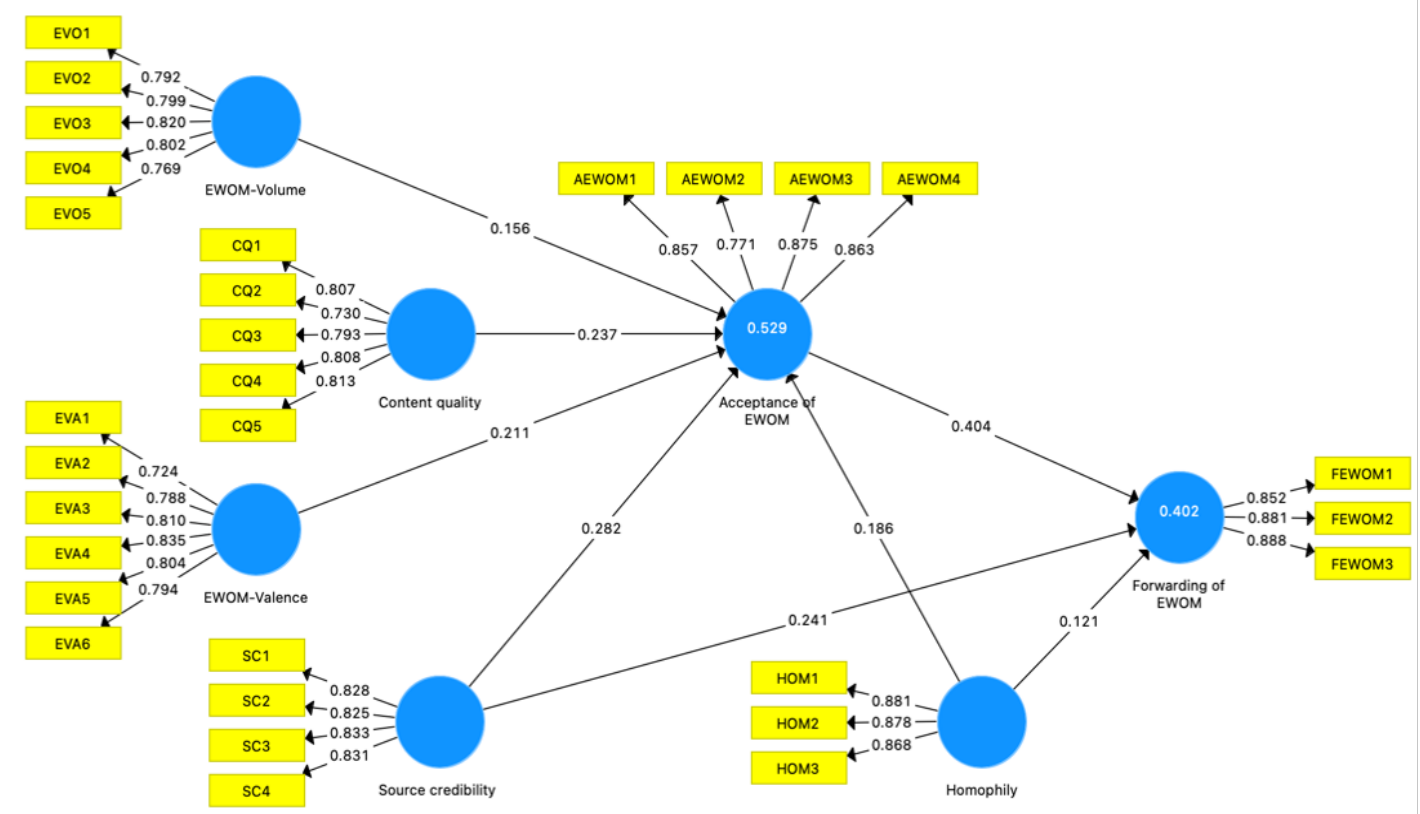

Figure 2. Measurement Model

\section{Discussion}

Unlike previous studies that primarily investigated the impact of EWOM on purchase intention or sales, this study aims to explore the relationship between five antecedents, namely EWOM volume, content quality, EWOM valence, source credibility, and homophily, on acceptance and forwarding of EWOM. This research found that all hypothesized relationships from $\mathrm{H} 1$ to $\mathrm{H} 8$ are well supported. When customers accept the EWOM message, the likelihood that they subsequently forward the EWOM is higher. This implies that people need to verify the information before passing the message to others. Moreover, to lower risks of providing incorrect information, causing other people to make the wrong decision and harming the personal reputation and social relationships. Source credibility is the most critical factor seeing the most significant effect on both AEWOM and FEWOM among the examined antecedents, showing that customers trust, accept, and forward information from an expert, which aligns with Sweeney et al. (2008). Although forwarding decision is also positively affected by homophily, source credibility has a greater impact on it. Next, good content quality is also crucial in the "central" route that customers base on to accept the information's truthfulness and validity. People tend to accept the EWOM information relevant to what they seek and post images or videos. This is in line with the focus group of Mazzarol et al. (2007), Nguyen (2021), indicating that people likely accept information that fits their needs. Analysis results also demonstrate the positive influence of EWOM volume, EWOM valence, and homophily on customers' acceptance of EWOM, but the effects are smaller than source credibility. 


\section{Implications}

This study has some theoretical implications for EWOM literature. The first contribution is that research sources on EWOM mainly focus on the impacts of EWOM determinants on purchasing intention, behavior, or sales. Those on acceptance and forwarding of EWOM are still limited. Thus, this work has contributed to examining these aspects using two processing-information routes in Elaboration Likelihood Model.

Practically, this research has numerous contributions to practitioners, managers, and e-marketers. Firstly, based on these findings, businesses can understand more deeply the influence of acceptance and forwarding of EWOM and factors influencing them, including EWOM volume, EWOM valence, content quality, source credibility, and homophily, which increase marketing activities effectiveness. The most commonly appreciated factor - source credibility in the "peripheral" route - requires companies to collaborate with opinion leaders, requesting them to share their consumption experience. Such collaboration will spread brand and product information to more people and also allow product/service improvement. In another perspective, companies must have channels to monitor complaints of opinion leaders or trustworthy reviewers to avoid negative EWOM going viral (Mahapatra \& Mishra, 2017). The finding strengthens this implication that unfavorable information is generally more influential than favorable information (Fiske, 1980; Skowronski and Carlston, 1987; Chiou and Cheng, 2003). Furthermore, companies need to respond to consumers' complaints with sincerity, apologize if appropriate, explain if possible, and a prompt solution for product or service problems (Mahapatra \& Mishra, 2017). These actions will give consumers a sense of assurance and value instead of merely being a buyer contributing to companies' sales.

Findings of the significance of good content quality also recommend that businesses encourage consumers' word-of-mouth information that is complete, detailed, relevant, correct, and attached with videos or images. This can be done by giving special offers such as cashback, promotions for those who posted reviews satisfying some certain conditions. As a result, providing the most complete and trustworthy information source for future customers and boosting sales.

\section{Research Limitation and Future Direction}

Despite several significant findings in this study, some limitations can enable further research in the future. Firstly, this work ignores a critical variable - customer mood - which directly influences the forwarding of EWOM. Mansour \& Farmanesh (2020) reported a positive relationship between customer mood and EWOM receivers' decision to forward the EWOM information. Secondly, the present study did not examine the culture that plays the moderating role in the relationship between acceptance and forwarding of electronic word of mouth. For example, Fukushige et al. (2019) investigated the moderating roles of Hofstede's cultural dimensions. They indicated that among the five cultural dimensions, power distance, collectivism, and masculinity significantly moderated the AEWOM -> FEWOM relationship. Therefore, further research shall discuss and consider the variables, including customer mood or culture, in the research model to gain a deeper insight into acceptance and forwarding of electronic word of mouth. 


\section{References}

Ab Hamid, M. R., Sami, W., \& Sidek, M. M. (2017, September). Discriminant validity assessment: Use of Fornell \& Larcker criterion versus HTMT criterion. Journal of Physics: Conference Series 890(1), 012-163.

Abd-Elaziz, M. E., Aziz, W. M., Khalifa, G. S., \& Abdel-Aleem, M. (2015). Determinants of Electronic word of mouth (EWOM) influence on hotel customers' purchasing decision. International Journal of Heritage, Tourism, and Hospitality, 9(2/2), 194-223.

Abrantes, J. L., Seabra, C., Lages, C. R., \& Jayawardhena, C. (2013). Drivers of in-group and outof-group electronic word-of-mouth (eWOM). European Journal of Marketing, 47(07), 1067 $-1088$.

Ahmed, S., \& Latif, W. B. (2018). Measuring Customer-Based Brand Equity and Brand Competitiveness: An Empirical Study of Minister Brand in Bangladesh. Journal of International Business and Management, 1(3), 1-14.

Al-Htibat, A. \& Garanti, Z. (2019). Impact of interactive eReferral on tourists behavioural intentions. Marketing Intelligence and Planning, 37(5), 527-541.

Amblee, N., \& Bui, T. (2011). Harnessing the influence of Social Proof in Online Shopping: The effect of Electronic Word of Mouth on Sales of Digital Microproducts. International Journal of Electronic Commerce, 16(2), 91-113.

Andersen, O., \& Kheam, L. S. (1998). Resource-based theory and international growth strategies: an exploratory study. International Business Review, 7 (2), 163-184.

Andersen, P. A., \& Todd de Mancillas, W. R. (1978). Scales for the measurement of homophily with public figures. Southern Journal of Communication, 43(2), 169-179.

Arndt, J. (1967). Role of product-related conversations in the diffusion of a new product. Journal of Marketing Research, 4(3), 291-295.

Awad, N. F., \& Ragowsky, A. (2008). Establishing trust in electronic commerce through online word of mouth: An examination across genders. Journal of Management Information Systems, 24(4), 101-121.

Baka, V. (2016). The becoming of user-generated reviews: Looking at the past to understand the future of managing reputation in the travel sector. Tourism Management, 53, 148-162.

Banerjee, A. V. (1992). A simple model of herd behaviour. The Quarterly Journal of Economics, 107(3), 797-817.

Bhattacherjee, A. and Sanford, C. (2006). Influence processes for information technology acceptance: An elaboration likelihood model. MIS Quarterly, 30(4), 805-825.

Blau, P.M. (1964), Exchange and Power in Social life. New York, NY: Wiley.

Bordia, P., Irmer, B.E. and Abusah, D. (2006), "Differences in sharing knowledge interpersonally and via databases: The role of evaluation apprehension and perceived benefits", European Journal of Work and Organizational Psychology, 15(3), pp. 262-280.

Brown, J., Broderick, A. J., \& Lee, N. (2007). Word of mouth communication within online communities: Conceptualizing the online social network. Journal of Interactive Marketing, 21(3), 2-20.

Bryman, A., \& Bell, E. (2011). Business Research Methods 3rd ed. New York.

Cacioppo, J. T., \& Petty, R. E. (1989). Effects of message repetition on argument processing, recall, and persuasion. Basic and applied social psychology, 10(1), 3-12.

Chan, Y. Y. Y. \& Ngai, E. W. T. (2011). Conceptualizing electronic word of mouth activity: an inputprocess- output perspective, Marketing Intelligence \& Planning, 29(5), 488- 516.

Chen, Y., Wang, Q., \& Xie, J. (2011). Online social interactions: A natural experiment on word of mouth versus observational learning. Journal of Marketing Research, 48(2), 238-254.

Cheung, C. M., \& Thadani, D. R. (2012). The impact of electronic word-of- mouth communication: A literature analysis and integrative model. Decision Support Systems, 54(1), 461-470.

Cheung, C. M., Lee, M. K., \& Rabjohn, N. (2008). The impact of electronic word-of-mouth: The adoption of online opinions in online customer communities. Internet Research, 18(3), 229247. 
Cheung, M. Y., Luo, C., Sia, C. L., \& Chen, H. (2009). Credibility of electronic word-of-mouth: Informational and normative determinants of online consumer recommendations. International Journal of Electronic Commerce, 13(4), 9-38.

Chiou, J. S., \& Cheng, C. (2003). Should a company have message boards on its web sites?. Journal of Interactive Marketing, 17(3), 50-61.

Cho, S., Huh, J., \& Faber, R. J. (2014). The influence of sender trust and advertiser trust on multistage effects of viral advertising. Journal of Advertising, 43(1), 100-114.

Chu, S. C., \& Kim, Y. (2011). Determinants of consumer engagement in electronic word-of-mouth (eWOM) in social networking sites. International journal of Advertising, 30(1), 47-75.

Cohen, J. (1988). Statistical power analysis for the behavioral sciences. Hillsdale, NJ: Lawrence Erlbaum.

Collis, J., \& Hussey, R. (2014). Business research: a practical guide for undergraduate \& postgraduate students. $4^{\text {th }}$ ed. Basingstoke: Palgrave Macmillan.

De Bruyn, A., \& Lilien, G. L. (2008). A multi-stage model of word-of-mouth influence through viral marketing. International journal of research in marketing, 25(3), 151-163.

DeLone, W. H., \& McLean, E. R. (2003). The DeLone and McLean model of information systems success: a ten-year update. Journal of Management Information Systems, 19(4), 9-30.

Dobele, A., Lindgreen, A., Beverland, M., Vanhamme, J., \& Van Wijk, R. (2007). Why pass on viral messages? Because they connect emotionally. Business Horizons, 50(4), 291-304.

Duan, W., Gu, B., \& Whinston, A. B. (2008). The dynamics of online word-of- mouth and product sales-An empirical investigation of the movie industry. Journal of Retailing, 84(2), 233242.

Eldesouky, M. M. K. (2011). Exploring viral marketing and its impact on consumer buying behavior with implications for Egypt.

Fan, Y. W., \& Miao, Y. F. (2012). Effect of electronic word-of-mouth on consumer purchase intention: The perspective of gender differences. International Journal of Electronic Business Management, 10(3), 175.

Fan, Y. W., Miao, Y. F., Fang, Y. H., \& Lin, R. Y. (2013). Establishing the adoption of electronic word-of-mouth through consumers' perceived credibility. International Business Research, $6(3), 58$.

Feldman, J. M., \& Lynch, J. G. (1988). Self-generated validity and other effects of measurement on belief, attitude, intention, and behavior. Journal of applied Psychology, 73(3), 421.

Filieri, R., \& McLeay, F. (2014). E-WOM and accommodation: An analysis of the factors that influence travelers' adoption of information from online reviews. Journal of Travel Research, 53(1), 44-57.

Fiske, S. T. (1980). Attention and weight in person perception: The impact of negative and extreme behavior. Journal of personality and Social Psychology, 38(6), 889.

Fukushige, A., Aryupong, M., \& Phijaranakul, P. (2019). Moderating Effects of Hofstede's Cultural Dimensions on Relationship between AEWOM and FEWOM in Thailand. ABAC Journal, 39(2).

Gershoff, A. D., Mukherjee, A., \& Mukhopadhyay, A. (2003). Consumer acceptance of online agent advice: Extremity and positivity effects. Journal of Consumer Psychology, 13(1-2), 161-170.

Gilly, M. C., Graham, J. L., Wolfinbarger, M. F., \& Yale, L. J. (1998). A dyadic study of interpersonal information search. Journal of the Academy of Marketing Science, 26(2), 83100.

Godes, D., \& Mayzlin, D. (2009). Firm-created word-of-mouth communication: Evidence from a field test. Marketing science, 28(4), 721-739.

Gupta, P., \& Harris, J. (2010). How e-WOM recommendations influence product consideration and quality of choice: A motivation to process information perspective. Journal of Business Research, 63(9-10), 1041-1049.

Hair Jr, J. F., Hult, G. T. M., Ringle, C. M., \& Sarstedt, M. (2016). A primer on partial least squares structural equation modeling (PLS-SEM). Sage publications. 
Hair Jr, J. F., Matthews, L. M., Matthews, R. L., \& Sarstedt, M. (2017). PLS-SEM or CB-SEM: updated guidelines on which method to use. International Journal of Multivariate Data Analysis, 1(2), 107-123.

Hair Jr, J. F., Sarstedt, M., Hopkins, L., \& Kuppelwieser, V. G. (2014). Partial least squares structural equation modeling (PLS-SEM): An emerging tool in business research. European Business Review, 26(2), 106-121.

Hair, J. F., Black, W. C., Babin, B. J., Anderson, R. E., \& Tatham, R. L. (2010). Multivariate Data Analysis, $7^{\text {th }}$ Edn New York. NY: Pearson.

Hansen, M. T. (1999). The search-transfer problem: The role of weak ties in sharing knowledge across organization subunits. Administrative Science Quarterly, 44(1), 82-111.

Hass, R. G. (1981). Effects of source characteristics on cognitive responses in persuasion. Cognitive Responses in Persuasion, 141-172.

Hennig-Thurau, T., Gwinner, K. P., Walsh, G., \& Gremler, D. D. (2004). Electronic word-of-mouth via consumer-opinion platforms: what motivates consumers to articulate themselves on the Internet?. Journal of Interactive Marketing, 18(1), 38-52.

Herr, P. M., Kardes, F. R., \& Kim, J. (1991). Effects of word-of-mouth and product-attribute information on persuasion: An accessibility-diagnosticity perspective. Journal of Consumer Research, 17(4), 454-462.

Hu, L. T., \& Bentler, P. M. (1998). Fit indices in covariance structure modeling: Sensitivity to underparameterized model misspecification. Psychological Methods, 3(4), 424.

Hu, N., Bose, I. and Liu, Y.G. (2011), "Manipulation in digital word-of-mouth: A reality check for book reviews", Decision Support Systems, 50(3), pp. 627-635.

Huang, M., Cai, F., Tsang, A. S., \& Zhou, N. (2011). Making your online voice loud: the critical role of WOM information. European Journal of Marketing. 45(7/8). 1277-1297.

Jiménez, F. R., \& Mendoza, N. A. (2013). Too popular to ignore: The influence of online reviews on purchase intentions of search and experience products. Journal of Interactive Marketing, 27(3), 226-235.

Kudeshia, C., \& Kumar, A. (2017). Social eWOM: does it affect the brand attitude and purchase intention of brands?. Management Research Review, 40(03), 310-330.

Labrecque, L. I., vor dem Esche, J., Mathwick, C., Novak, T. P., \& Hofacker, C. F. (2013). Consumer power: Evolution in the digital age. Journal of interactive marketing, 27(4), 257-269.

Latané, B. (1981). The psychology of social impact. American Psychologist, 36(4), 343.

Lee, M., Rodgers, S., \& Kim, M. (2009). Effects of valence and extremity of eWOM on attitude toward the brand and website. Journal of Current Issues \& Research in Advertising, 31(2), $1-11$.

Lin, C. A., \& Xu, X. (2017). Effectiveness of online consumer reviews: The influence of valence, reviewer ethnicity, social distance and source trustworthiness. Internet Research, 27(2), 362380.

Lin, C., Wu, Y. S., \& Chen, J. C. V. (2013). Electronic word-of-mouth: The moderating roles of product involvement and brand image. TIIM 2013 Proceedings, 43(2013), 39-47.

Lin, T. M., Lu, K. Y., \& Wu, J. J. (2012). The effects of visual information in eWOM communication. Journal of Research in Interactive Marketing.

Luo, C., Wu, J., Shi, Y., \& Xu, Y. (2014). The effects of individualism-collectivism cultural orientation on eWOM in- formation. International Journal of Information Management, 34(4), 446-456.

Mahapatra, S. \& Mishra, A. (2017). Acceptance and forwarding of electronic word of mouth. Marketing Intelligence and Planning, 35(5), 594-610.

Mangold, W. G., \& Faulds, D. J. (2009). Social media: The new hybrid element of the promotion mix. Business Horizons, 52(4), 357-365.

Mansour, O., \& Farmanesh, P. (2020). Does gender matter? Acceptance and forwarding of electronic word of mouth: A moderated mediation analysis. Management Science Letters, 10(7), 14811486 . 
Mazzarol, T., Sweeney, J. C., \& Soutar, G. N. (2007). Conceptualizing word-of-mouth activity, triggers and conditions: an exploratory study. European Journal of Marketing, 41(11-12), $1475-1494$.

Menkveld, B. G. T. (2013). Exploring credibility in electronic word-of- mouth (Master's thesis, University of Twente).

Mishra, A., \& Satish, S. M. (2016). eWOM: Extant research review and future research avenues. Vikalpa, 41(3), 222-233.

Nielsen. (2012), "Global online consumers and multi-screen media: Today and tomorrow", (Online), Avaiable at: http://www.scientificamerican.com/article.cfm?id=manipulation-of-the-crowd. Accessed on 15/6/2021.

NGUYEN, H. N. (2021). Antecedents and Consequences of Brand Hate Among Netizens: Empirical Evidence from Vietnam. The Journal of Asian Finance, Economics and Business, 8(7), 579589.

Nunnally, J.C, \& Bernstein, I.H. (1994). Psychometric Theory (3rd ed.). New York: McGraw-Hill.

Ohanian, R. (1990). Construction and validation of a scale to measure celebrity endorsers' perceived expertise, trustworthiness, and attractiveness. Journal of Advertising, 19(3), 39-52.

Park, D. H., Lee, J., \& Han, I. (2007). The effect of online consumer reviews on consumer purchasing intention: The moderating role of involvement. International Journal of Electronic Commerce, 11(4), 125-148.

Park, D.H. and Lee, J. (2008), "eWOM overload and its effect on consumer behavioural intention depending on consumer involvement", Electronic Commerce Research and Applications, 7(4).

Petty, R. E., \& Cacioppo, J. T. (1986). The elaboration likelihood model of persuasion. In Communication and persuasion. Springer, New York, NY.

Petty, R. E., Cacioppo, J. T., \& Goldman, R. (1981). Personal involvement as a determinant of argument-based persuasion. Journal of Personality and Social Psychology, 41(5), 847.

Pongjit, C., \& Beise-Zee, R. (2015). The effects of word-of-mouth incentivization on consumer brand attitude. Journal of Product \& Brand Management, 24(07), 720-735.

Ramayah, T., Lee, J. W. C., \& In, J. B. C. (2011). Network collaboration and performance in the tourism sector. Service Business, 5(4), 411-428.

Rahman, M. A., \& Haque, M. S. (2021). Customer-Perceived Value on Samsung and Apple Smartphone: A Comparative Study on Japanese and Bangladesh University Students. Journal of International Business and Management, 4(7), 01-20.

Rogers, E. M. 1995. Diffusion of Innovations. New York: The Free Press.

Rogers, E. M., \& Bhowmik, D. K. (1970). Homophily-heterophily: Relational concepts for communication research. Public Opinion Quarterly, 34(4), 523-538.

Saunders, M., Lewis, P., \& Thornhill, A. (2012). Research Methods for Business Students. 6th ed. Harlow: Pearson Education Limited.

Schindler, R. M., \& Bickart, B. (2012). Perceived helpfulness of online consumer reviews: The role of message content and style. Journal of Consumer Behaviour, 11(3), 234-243.

Sekaran, U. \& Bougie, R. (2010). Research methods for business: A skill building approach (5th ed.). Chichester: John Willey \& Sons Ltd

Shiu, E., Hair, J., Bush, R. \& Ortinau, D. (2009). Marketing Research. 1st edition. Berkshire: McGraw- Hill Education.

Skowronski, J. J., \& Carlston, D. E. (1987). Social judgment and social memory: The role of cue diagnosticity in negativity, positivity, and extremity biases. Journal of Personality and Social Psychology, 52(4), 689.

Srivastava, M., \& Sivaramakrishnan, S. (2020). The impact of eWOM on consumer brand engagement. Marketing Intelligence \& Planning, 39(3), 469-484.

Steffes, E. M., \& Burgee, L. E. (2009). Social ties and online word of mouth. Internet Research, $19(1), 42-59$. 
Sun, T., Youn, S., Wu, G., \& Kuntaraporn, M. (2006). Online word-of-mouth (or mouse): An exploration of its antecedents and consequences. Journal of Computer-Mediated Communication, 11(4), 1104-1127.

Sundar, S. S. (1998). Effect of source attribution on perception of online news stories. Journalism \& Mass Communication Quarterly, 75(1), 55-68.

Sussman, S. W., \& Siegal, W. S. (2003). Informational influence in organizations: An integrated approach to knowledge adoption. Information Systems Research, 14(1), 47-65.

Sweeney, J. C., Soutar, G. N., \& Mazzarol, T. (2008). Factors influencing word of mouth effectiveness: receiver perspectives. European Journal of Marketing, 42(3/4), 344-364.

Sweeney, J., Soutar, G., \& Mazzarol, T. (2014). Factors enhancing word-of-mouth influence: positive and negative service-related messages. European Journal of Marketing, 48(1/2), 336-359.

Tellis, G. J. (1988). The price elasticity of selective demand: A meta-analysis of econometric models of sales. Journal of Marketing Research, 25(4), 331-341.

Teng, S., Khong, K. W., Goh, W. W., \& Chong, A. Y. L. (2014). Examining the antecedents of persuasive eWOM messages in social media. Online Information Review, 38(6), 746-768.

Thelwall, M. (2009). Homophily in myspace. Journal of the American Society for Information Science and Technology, 60(2), 219-231.

Van den Bulte, C., \& Lilien, G. L. (2001). Medical innovation revisited: Social contagion versus marketing effort. American Journal of Sociology, 106(5), 1409-1435.

Veer, E. (2011b). Staring: How Facebook Facilitates the Breaking of Social Norms. Research in Consumer Behavior, 185-198.

Vilpponen, A., Winter, S., \& Sundqvist, S. (2006). Electronic word-of-mouth in online environments: Exploring referral networks structure and adoption behavior. Journal of Interactive Advertising, 6(2), 8-77.

Wang, Z., Walther, J. B., Pingree, S., \& Hawkins, R. P. (2008). Health information, credibility, homophily, and influence via the Internet: Web sites versus discussion groups. Health communication, 23(4), 358-368.

Watts, S. A., \& Zhang, W. (2008). Capitalizing on content: Information adoption in two online communities. Journal of the Association for Information Systems, 9(2), 3.

Wu, C., \& Shaffer, D. R. (1987). Susceptibility to persuasive appeals as a function of source credibility and prior experience with the attitude object. Journal of Personality and Social Psychology, 52(4), 677.

Xiong, G., \& Bharadwaj, S. (2014). Prerelease buzz evolution patterns and new product performance. Marketing Science, 33(3), 401-421.

Yayli, A., \& Bayram, M. (2012). E-WOM: The effects of online consumer reviews on purchasing decisions. International Journal of Internet Marketing and Advertising, 7(1), 51-64.

\section{Appendix}

CQ

CQ1

CQ2

CQ3

CQ4

CQ5

EVO

EVO1 The more EWOM information about a product/service there is, the more trustworthy that information is.

EVO2 I believe in EWOM information if the majority of reviewers recommend them. 
EVO3 Highly ranking and recommendation infers that the product has good reputations.

EVO4 The more the brand is mentioned in front of me, the more I am aware of it.

EVO5 The more the brand is discussed in front of me, the more it influences my purchasing decision.

EVA

EVA1

EVA2

EVA3

EVA4

EVA5

EVA6

SC

$\mathrm{SC} 1$

$\mathrm{SC} 2$

$\mathrm{SC} 3$

SC4

HOM

HOM2

HOM3
HOM1

\section{EWOM Valence}

I believe in EWOM information with very high ratings or very low ratings.

I believe in consistent EWOM information, even though it is positive or negative.

I believe in positive EWOM information about products/services.

I believe in negative EWOM information about products/services.

I believe in neutral EWOM information about products/services.

Rankings help me select the best product/service among available alternatives.

\section{Source Credibility}

I believe in EWOM information from experts.

I believe in EWOM information from a person who I think has abundant knowledge of the product/service.

I believe in EWOM information from a person that I think has previous experience in the product/service.

I believe in EWOM information from a person that I think has the ability on judgment.

AEWOM

AEWOM1

AEWOM2

AEWOM3

AEWOM4

FEWOM

FEWOM1

I rely on EWOM information from a person who is in my age group.

I rely on EWOM information from a person who has the same interests as I do.

I rely on EWOM information from a person whose educational background is similar to mine.

"friends" list on social media sites when I find it useful.

FEWOM2 I am likely to pass along my contacts' comments containing information or opinions about the product that I like to other contacts.

FEWOM3 When I receive product related information or an opinion from a friend, I pass it along to my other contacts. 